\title{
Production of Ice Cream with Carob Bean Pekmez (Molasses)
}

\author{
Dr. Abdullah Badem ${ }^{1}$, Dr. Zafer Alpkent ${ }^{2}$
}

\author{
${ }^{1}$ Selcuk University, Veterinary Faculty, Food Hygiene and Technology Department, Konya, Turkey \\ ${ }^{2}$ Asst. Prof., Mediterranean University, Engineering Faculty, Food Engineering Department, Antalya, Turkey
}

\begin{abstract}
Day to day, it is known that people are giving importance to nutrition their diets in terms of health. Whether or not the materials used in the production of food are natural, the amount used in production and effect on human health have become more important. In this study, low-fat ice cream was produced with rich composition carob molasses (pekmez), which has a positive contribution to nutrition, and the effect on ice cream was investigated. Physical and chemical analysis results of ice cream, pH 6,31, dry matter 27,23\%, fat $3,50 \%$, protein $3,86 \%$, overrun $18,99 \%$ and viscosity (10 rpm-20 rpm-50 rpm) 11.840, 6.560, $3.344 \mathrm{cP}$, was found. As a result, a new product has been made which can be used in ice cream production of carob molasses.
\end{abstract}

Keywords-Carob, carob molasses, low-fat ice cream.

\section{INTRODUCTION}

Ice cream, and all other frozen desserts, usually consist of seven ingredients: Fat, nonfat dry milk, sweeteners, stabilizers, emulsifiers, water and flavoring agents. Although frozen desserts are a very large area, the production of all of them is similar.

Ice cream is a milk product obtained by mixing, pasteurizing, homogenizing, cooling and freezing of pasta ingredients (Goff, 1997: 365, Arbuckle, 1986: 1, Goff ve Hartel, 2013:1). Ice cream is defined as "ice cream, milk and other dairy products, water, sugar and/or additives are mixed at a certain ratio, when desired, by the addition of salep, egg and/or flavoring and which is prepared and packaged according to its technique after being pasteurized and flavoring substances are added in various forms when necessary" at Turkish standards 4265. (TSE, 1992). Marshall and Arbuckle (1996: 315) described the composition of an economical ice cream as $35-37 \%$ total dry matter, consisting of $10 \%$ milk fat, $10-11 \%$ nonfat dry matter, $15 \%$ flavor, $0,3 \%$ stabilizer and emulsifier.

It is known that instead of synthetically produced products in the world, tendency to natural products increases. Along with consumption of high-energy food, immobile life of mankind triggers obesity. The nutrition diet consists of processed foods, low fiber and high fat saturated fat and sugar content, with low physical activity, poses a serious threat to health and causes important diseases such as obesity, coronary heart disease, diabetes and cancer. (Koeferli vd., 1996:1, Popkin ve Larsen, 2004:2). For this reason, consumers tend to deviate from the consumption of known fatty foods, which have a significant impact on human health.

Carob (Ceratonia siliqua L.) is a plant belonging to the Ceratonia genus of the Leguminosae family and is grown in regions where the Mediterranean climate dominates (Turhan vd., 2007: 417, Tetik vd., 2010: 1, El Batal vd., 2016: 1). Carob has $91-92 \%$ dry matter and $62-67 \%$ total soluble dry matter when it matures. A significant portion of soluble dry matter forms saccharose (34-42\%), fructose (10-12\%) and glucose (7-10\%) (Karkacier ve Artık 1995:). Other studies have shown that carob molasses has a total sugar content of 60-70\% (Ekşi ve Artık 1986:, Şimşek ve Artık 2002: 465, Turhan vd., 2007: 418, Tetik vd., 2010: 41).

Carob is composed of two parts: fruit pulp (pod) (90\%) and seed $(10 \%)$. From the pulp part of carob, grape molasses, carob flour and animal food products are produced and locust bean gum (LBG), which is used as a stabilizer in food and other areas (which form a very viscous solution even when used in low quantities), is produced from the core part. LBG is synergistic with carrageenan, agar and xanthan gum, creating a very strong and elastic gel (Kumazawa vd., 2002: 373, El Batal vd., 2016: 956). It is estimated that 200,000 hectares per year of the world produce over 300,000 tons of carob fruit (El Batal vd., 2016: 955, Vekiari vd. 2011: 751). It is determined that there are 370.000 carob tree trees in Turkey and that 13,985 thousand tons of carob bean is produced in 2015 (TSI, 2016).

Pekmez (molasses) is produced as a traditional product in Turkey for many years. Pekmez is produced from fruits with high sugar content such as grape, apple, carob, plum, watermelon, apricot, fig, sugar beet, hawthorn, mulberry, raisins, corn, sugar cane (Üstün ve Tosun, 1997:417, Şimşek ve Artık 2002: 460, Özdemir vd., 2004: 33, Karababa ve Işıkl, 2005: 357, Sengül vd., 2007:39).

Grape molasses is defined as "grape pekmez is a thick liquid food which is produced adding honey, cow milk, milk powder, egg, by vacuuming or thickening in accordance with the technique, without reducing the 
acidity of the fresh or raisin extract, or by reducing its acidity with calcium carbonate or sodium carbonate, followed by drying with tannin gelatin or suitable enzymes" at TS 3792 (TSE, 1989). Molasses is added to obtain the desired flavor and color in ice cream production, as well as to control the freezing point of ice cream (Temiz ve Yeşilsu, 2010: 539). Although the molasses compositions vary according to the fruit obtained, the basic composition is carbohydrates (Şimşek ve Artık 2002: 460, Karababa ve Işıklı, 2005: 357). The first order of pekmez production in Turkey is grape (Üstün ve Tosun, 1997:417).

Carob molasses is a traditional product produced in Turkey for many years from the fruits of Ceratonia siliqua L. plant. As it is not possible to directly press the fruit which reaches the consumption level, it is extracted with water. For this, the carob is broken down in sizes of 5 and $7 \mathrm{~mm}$, then moistened with water and extruded at $85^{\circ} \mathrm{C}$ for 3 hours. After the extraction, perlite is filtered with molasses soil containing bentonite (containing 50-90\% calcium carbonate) to neutralize acidity. After then, the extract is concentrated by evaporation at $85^{\circ} \mathrm{C}$ to $65-70^{\circ}$ Briks and the extract is pasteurized against microbial growth and deterioration. The final product is filled hermetically in glass jars (Demirözü vd., 2002:330, Turhan vd., 2007: 39,40, Tetik vd., 2010: 418).

As with other molasses, carob pekmez is rich in carbohydrates and mineral substances and is an important food material especially for children in the age of growth, pregnant women, suckling mothers, athletes and workers, who need high energy. It is especially important in terms of mineral substances such as potassium, calcium, phosphorus, magnesium and iron. (Demirözü vd., 2002: 330-333, Şimşek ve Artık 2002:465, 467, Vekiari vd. 2011: 751).

Carob is widely used in the world for industry, afforestation, prevention of erosion, ornamentation, painting, food, animal feed and medical treatment. Carob is widely used medicinally for the treatment of many diseases such as flu, cough, asthma, bronchitis, wound healing, diarrhea, intestinal draining, reflux, nail fractures, anemia, blood disorders, prostate, fatigue, cholesterol, diabetes, urinary infections, liver, kidney, stomach, intestineand lung treatment (Bulut, 2006: 65, Güneş, 2010: 87, Gürdal, 2010: 121,122, Dakia, 2011: 293, Akbulut ve Bayramoglu, 2013: 67, Yildırım ve Kargioğlu 2015: 104,106,107).

In this study, a low-fat ice cream was produced using carob pekmez in ice cream production, giving people the opportunity to choose a new variety of products with different flavors and aromas. In the production of ice cream, instead of synthetic materials, xanthan, carrageenan and locust bean gums were used as natural stabilizers and the effect on some properties of ice cream is investigated.

\section{MATERIAL AND METHOD}

\subsection{Material}

Used in the production of ice cream, UHT milk, skimmed milk powder, butter, sucrose, locust bean pekmez and LBG, carrageenan and xanthan gum, was given properties Table 1 and Table 2, were supplied from Antalya. Ice cream production was carried out at a milk processing plant operating under the Food Engineering Department of the Faculty of Agriculture, Akdeniz University.

\subsection{Method}

\subsubsection{Production of Ice Cream}

Before the production of carob ice cream was carried out for the study, 5 different sugar-molasses mixtures were used in preliminary experiments and molasses and sugar amount to be used by sensory evaluation were determined. Stabilizer usage ratios were determined based on the data obtained from the literature and were determined in the study of Badem (2006: 51). (Marshall ve Arbuckle 1996: 29, 72-75, Vega vd., 2004:). At the end of the study conducted by Badem (2006: 51), the best ice cream from sensory evaluation was selected as carrageenan gum at $0,1 \%$, xanthan gum at $0,1 \%$ and locust bean gum at $0,4 \%$. Amounts of the substances involved in ice cream production; For a 2600 gram mix; 2 liters of milk, 300 grams of molasses, 200 grams of sucrose, 70 grams of milk powder, 30 grams of butter. The fat content of the frozen is set at $3,5 \%$.

Table.1: Some properties of ingredients used in ice cream production.

\begin{tabular}{lccccccc}
\hline Analyses & UHT Milk & Butter & $\begin{array}{c}\text { Milk } \\
\text { powder }\end{array}$ & Sucrose & $\begin{array}{c}\text { Carragenan } \\
\text { gum }\end{array}$ & $\begin{array}{c}\text { Xsantha } \\
\text { n gum }\end{array}$ & LBG \\
\hline Dry matter (\%) & 11,13 & - & 92,50 & 98,88 & 82,00 & 91,50 & 90,00 \\
\hline Fat (\%) & 3,10 & 82,50 & - & - & - & - & - \\
\hline Protein (\%) & 3,13 & - & - & - & - & - & - \\
\hline pH & 6,38 & - & - & - & - & - & - \\
\hline
\end{tabular}


Ice cream production is started by mixing powdered ingredients. Then, 2 liters of milk heated to $60^{\circ} \mathrm{C}$ was added slowly, so that the mixture didn't clump. This mixture was pasteurized at $80^{\circ} \mathrm{C}$ for 10 minutes, then rapidly cooled to $30^{\circ} \mathrm{C}$. 300 grams of molasses was added to each mix that was cooled. After matured at $4^{\circ} \mathrm{C}$ for 24 hours, produced ice cream mix were frozen at $-5^{\circ} \mathrm{C}$ with semi-continuous Uğur brand freezing machine. The ice cream processing time was 15 minutes for each mix and was packed. Then, hardening was carried out for 24 hours in the deep freeze at $-11^{\circ} \mathrm{C}$. The prepared ice cream was kept at this temperature until analysis was made.

\section{Table.2: Some qualities of molasses used in ice cream} production.

\begin{tabular}{lc}
\hline \multicolumn{1}{c}{ Parameters* } & $(\%)$ \\
\hline Dry matter & 66,91 \\
\hline Carbohydrate & 62,50 \\
\hline Lipid & 0,41 \\
\hline Protein & 4,00 \\
\hline Ash & 2,40 \\
\hline Total sugar & 62,00 \\
\hline Invert sugar & 17,25 \\
\hline \multicolumn{1}{c}{ Minerals } & $(\mathbf{m g} / \mathbf{k g})$ \\
\hline Potassium & 7040 \\
\hline Calsium & 1234 \\
\hline Phosphorus & 547 \\
\hline Magnezyum & 500 \\
\hline Sodium & 203 \\
\hline Zinc & 10 \\
\hline Iron & 7,6 \\
\hline Manganese & 3,0 \\
\hline Copper & 0,8 \\
\hline
\end{tabular}

* The information on the table was taken from Kimtek Co. (Antalya).

\subsubsection{Analysis in ice cream}

pH analysis: After ice cream samples were melted at $20^{\circ}$ $\mathrm{C}$, they were determined using a Hanna instruments 8519 brand $\mathrm{pH}$ meter.

Dry matter analysis: The dry matter content of ice cream samples was determined according to TS 4265 Ice Cream Standard (TSE, 1992).

Protein analysis: Amounts of protein in ice cream samples were determined by the Kjeldahl Method (AOAC, 1999: 13).

Overrun analysis: Overrun in ice cream was determined as Arbuckle (1986: 187) method.
Viscosity analysis: The method given by Chang and Hartel (2002) was used for measuring.Viscosity of mix added pekmez was determined by measuring the Brookfield Viscosimeter (R.V.T.) at $10 \mathrm{rpm}, 20 \mathrm{rpm}$ and $50 \mathrm{rpm}$ at $25^{\circ} \mathrm{C}$ and was measured 30 seconds after the viscosimetric tip was immersed in.

\section{RESULT}

Physical and chemical analysis results of ice cream produced as described in Material and Method are given in Table 3 . The obtained data were given by averaging the replicate analyzes.

Tablo.3: Analysis results of ice cream.

\begin{tabular}{lr}
\hline Parameters & Value \\
\hline pH & 6,31 \\
\hline Dry matter (\%) & 27,23 \\
\hline Fat (\%) & 3,50 \\
\hline Protein (\%) & 3,86 \\
\hline Overrun (\%) & 18,99 \\
\hline Viscosity (10 rpm-cP) & 11.840 \\
\hline Viscosity (20 rpm-cP) & 6.560 \\
\hline Viscosity (50 rpm-cP) & 3.344 \\
\hline
\end{tabular}

\section{CONCLUSION}

The effect of pekmez used at $11 \%$ and stabilizers $(0,1 \%$ carrageenan gum, $0,1 \%$ xanthan gum and $0,4 \%$ LBG) in ice cream production, the values of $\mathrm{pH}$, dry matter, protein and viscosity values obtained in the study, have similarity in comparison with other studies (Koçan ve Koçak, 2002:372, Keçeli ve Konar (2003: 417, Güven vd., 2010: 100, Temiz ve Yeşilsu (2010: 541, 542). Keçeli et al. (1997: 180) investigated the effects of sahlep and some alternative stabilizers on the quality of ice cream produced with goat milk. Accordingly, depending on type of stabilizer used, the properties of ice cream mix have also changed. The highest overrun values were found in ice cream adding LBG and sahlep $36,1 \%$ and $35,8 \%$, respectively.

This value was calculated as $27,3 \%$ for control ice cream without any stabilizer. Again, Keçeli and Konar (2003: 417) investigated the effect of using LBG, CMC and gelatin in ice cream produced with cow milk. Overrun values were found between $30,65 \%$ - 38,17\%. The overrun, used LBG $0,5 \%$, ice cream was calculated as $36,93 \%$. Overrun of control ice cream produced $(0,25 \%$ LBG, 0,02\% carrageenan and 0,75\% guar gum, 5\% fat) by Atsan and Çağlar (2008) was determined as 25,26\%. Temiz and Yeşilsu (2010: 542) found that overrun rate decreased as the amount of molasses added to composition increased in ice cream produced using grape and mulberry molasses. In the production of $10 \%$ grape molasses and $10 \%$ mulberyy molasses were used in ice cream, overrun increase $19 \%, 21 \%$, respectively. Over- 
use of the stabilizers results in harder structured ice cream, so overrun is more limited. Also, LBG, carregen and xanthan gum interaction used limits overrun value (Marshall ve Arbuckle 1996: 34, 73). Overrun in this study, is $18,99 \%$, which is lower than other studies. As a result, it is determined that proportion of molasses used in ice cream production (11\%) and amount of stabilizer has effect on ice cream values.

In order to produce a new type of ice cream and to determine physical and chemical properties of ice cream, carob pekmez (molasses) was used as a natural sweetener besides sucrose. It has been determined that carob pekmez can be used for production of a new ice cream because of its high natural, ecological and nutritive value. It is also apparent that the low fat ice cream formulation can be achieved by use of suitable stabilizers.

\section{ACKNOWLEDGEMENTS}

This research was supported by Mediterranean University Research Projects Management Unit (Project number: 2005.02.0121.006) and contains some part of "The effect of carrageenan, xanthan and carob gums used in the production of carob pekmez ice cream on the quality of freezing" quoted from Master Thesis.

\section{REFERENCES}

[1] AKBUlUT, S., BAYRAMOGLU, M.M. (2013). The trade and use of some medical and aromatic herbs in turkey, Studies On Ethno-Medicine, 7(2): 67-77.

[2] AOAC, (1999) Official methods of analysis method 988.05.Ch.4, AOAC International, Gaithersburg, Md.

[3] ARBUCKLE, W.S. (1986) Ice cream, Westport, CT: AVI Publ. Co., Inc.

[4] ATSAN, E., ÇAĞLAR, A. (2008) The effect of different emulsifiers on some physical and sensory properties of ice cream, Atatürk University Journal of Agricultural Faculty, 39 (1): 75-81.

[5] BADEM, A. (2006) The effect of carrageenan, xanthan and carob gums used in the production of carob pekmez ice cream on the quality of freezing, Master Thesis, Mediterranean University, Antalya, Turkey.

[6] BULUT, Y. (2006) Useful Plants of Manavgat District (Antalya), Master Thesis, Süleyman Demirel University, Isparta, Turkey.

[7] CHANG, Y., HARTEL, RW. (2002) Stability of air cells in ice cream during hardening and storage, Journal of Food Engineering, 55: 59-70.

[8] DAKIA, P.A. (2011) Nuts and seeds in health and disease prevention, carob (ceratonia siliqua 1.) seeds, endosperm and germ composition, and application to health, Abstract, 293-299.

[9] DEMIRÖZÜ, B., SÖKMEN, M., UÇAK, A., YİLMAZ, H., GULDEREN, S. (2002) Variation of copper, iron, and zinc levels in pekmez products, Bulletin of Environmental Contamination and Toxicolology, 69: 330-334.

[10]EKŞİ, A., ARTIK, N. (1986) Harnup (carob) fruit and chemical compound of pekmez, Ankara University Faculty of Agriculture Annual, 36: 1, 7782.

[11]EL BATAL, H., HASIB, A., OUATMANE, A.,DEHBI, F., JAOUAD, A., BOULLI, A. (2016) Sugar composition and yield of syrup production from the pulp of moroccan carob pods (ceratonia siliqua L.), Arabian Journal of Chemistry, 9: 955959.

[12] GOFF, H. D. (1997) Colloidal aspect of ice cream a review, International Dairy Journal, 7: 363-373.

[13] GOFF, H.D., HARTEL, R.W. (2013) Ice cream, New York: Springer Science+Business Media.

[14] GÜNEŞ, S. (2010) Karaisalı (adana), and villages natural plants used by the public ethnobotanical respect investigation, Master Thesis, Niğde University, Niğde, Turkey.

[15] GÜRDAL, B. (2010) Ethnobotanical study in marmaris district (muğla), Master Thesis, İstanbul University, İstanbul, Turkey.

[16] GÜVEN, M., KARACA, O.B, YAŞAR, K. (2010) Effects on the properties of ice cream use of different emulsifiers in the production of low-fat kahramanmaraş-type ice cream, Food, 35(2): 97104.

[17] KARABABA, E., IŞIKLI, N.D. (2005) Pekmez: a traditional concentrated fruit pekmez, Food Reviews International, 21: 357-366.

[18] KARKACIER, M., ARTIK, N. (1995) Physical properties, chemical composition and extraction conditions of carob bean (ceratonia siliqua L.), Food, 20(3): 131-136.

[19] KEÇELİ, T., KONAR, A., ROBINSON, KK., (1997) Effect of sahlep and some alternative stabilizers on the qualities of goat milk ice cream. Ice Cream, Proceedings of the International Symposium, International Dairy Federation-ref. S.1. 9803, ISBN 9290-98-029-3, Belgium.

[20] KEÇELİ, T., KONAR, A. (2003) The effects of salep and alternative stabilizers on properties of cow milk ice cream, Food, 28 (4): 415-419.

[21] KOÇAN, D., KOÇAK, C. (2002) The effect of using quest admul mg 4143 emulsifiers at different concantrations on some properties of vanilla ice cream, Food, 27 (5): 369-377. 
[22] KOEFERLI, C.R.S., PICCINALI, P., SIGRIST, S. (1996) The influence of fat, sugar and non-fat milk solids on selected taste, flavor and texture parameters of a vanilla ice cream, Food Quality and Preference, 7 (2): 69-79.

[23] KUMAZAWA,S., TANIGUCHI, M., SUZUKI, Y., SHIMURA, M., KWON, M., NAKAYAMA, T., (2002) Antioxidant activity of polyphenols in carob pods, Journal of Agricultural and Food Chemistry, 50: 373-377.

[24] MARSHALL, R.T., ARBUCKLE, W.S. (1996) Ice cream. New York: International Thomson Pub.

[25] ÖZDEMIR F, TOPUZ, A., GÖLÜKCÜ, M., ŞAHIN, H. (2004) A study on improving process technique juniperus drupacea's fruit pekmez, Food, 29 (1): 33-40.

[26] POPKIN, B.M., LARSEN, P.G. (2004) The nutrition transition: worldwide obesity dynamics and their determinants, International Journal of Obesity, 28: 2-9.

[27] SENGÜL, M., ERTUGAY, M.F., SENGÜL, M., YÜKSEL, Y. (2007) Rheological characteristics of carob pekmez, International Journal of Food Properties, 10: 39-46.

[28] ŞiMŞEK, A., ARTIK, N. (2002) Studies of composition of concentrates from different fruit, Food, 27 (6): 459-467.

[29] TEMIZ, H., YEŞİLSU, A.F. (2010) Effect of pekmez addition on the physical, chemical, and sensory properties of ice cream, Czech Journal of Food Sciences, 28 (6): 538-546.

[30] TETIK, N., TURHAN, İ., KARHAN, M., ÖZIYCI, H.R. (2010) Characterization of, and 5hydroxymethylfurfural concentration in carob pekmez, Food, 35 (6): 417-422.

[31] TSE, (1989) TS 3792 "Grape molasses standard", Ankara, Turkey.

[32] TSE, (1992) TS 4265 " Ice cream-milk based "standard, Ankara, Turkey.

[33] TUIK, (2016) Turkish Statistical Institute, Ankara. www.tuik.gov.tr, access date:14.01.2016.

[34] TURHAN İ., TETIK, N., KARHAN, M. (2007) Composition and production stages of carob pekmez, Electronic Journal of Food Technologies, 2: 39-44.

[35] ÜSTÜN, N.,Ş., TOSUN, İ. (1997) Composition of pekmezs, Food, 22 (6): 417-423.

[36] VEGA, C., ANDREW, R. A., GOFF, H. D. (2004) Functionality of carrageenan in 1ce cream mix formulations, in ice cream II, ISBN: 92-9098-038-9. Brussels, Begium. pp. 78-87.

[37] VEKIARI A.S., OUZOUNIDOU, G., OZTURK, M., GÖRK, G. (2011) Variation of quality characteristics in greek and turkish carob pods during fruit development, Procedia Social and Behavioral Sciences, 19: 750-755.

[38] YILDIRIM, H.İ., KARGIOĞLU, M. (2015) The production and utilization of natural keçiboynuz (Ceratonia siliqua L.) syrup in alanya and gazipaşa districts of antalya. Afyon Kocatepe University Journal of Science and Engineering, 15: 102-108. 